\title{
Evolutionary design of selective adenosine receptor ligands
}

\author{
Horst van der Eelke*, J Kruisselbrink, A Aleman, MT Emmerich, Andreas Bender, AP IJzerman \\ From 5th German Conference on Cheminformatics: 23. CIC-Workshop \\ Goslar, Germany. 8-10 November 2009
}

Evolutionary de novo design is the design of new active compounds from scratch, using evolutionary principles. It involves an iterative cycle of structure generation, evaluation, and selection of candidate structures. Selected candidates serve as input for the next generation. By repeatedly selecting only the best structures as basis for structure generation, the process evolves toward better (not necessarily best) solutions. Here, we applied an evolutionary algorithm (the Molecule Commander) for the design of selective adenosine receptor ligands. Generated compounds were all rule-of- 5 compliant and had a polar surface areas between 0 and $140 \AA^{2}$, favorable for intestinal absorption. In addition, toxic compounds were filtered out using a categorical SVM model for prediction of mutagenicity trained on Ames-test mutagenicity data (5-fold ROC score: 0.8948). Four pharmacophores were designed, one for each human adenosine receptor subtype. The $\mathrm{hA}_{1}$ receptor pharmacophore served as objective for the evolution, while the three other pharmacophores served as negative objective in order to obtain selectivity. In order to measure similarity with known adenosine receptor ligands, ring systems and scaffolds in the generated compounds were compared with those extracted from adenosine ligands in the StARLITe database. With each new generation, the structures displayed an increasing number of ring systems also found in adenosine receptor ligands while the number of unique core structures (scaffolds) increased

Division of Medicinal Chemistry, Leiden/Amsterdam Center for Drug Research, Leiden University, Einsteinweg 55, 2333CC Leiden, The Netherlands as well. Eventually, the best (ADMET and pharmacophore score) candidate structures will be proposed for synthesis and tested for activity.

Published: 4 May 2010

\section{doi:10.1186/1758-2946-2-S1-P48}

Cite this article as: van der Eelke et al.: Evolutionary design of selective adenosine receptor ligands. Journal of Cheminformatics 2010 2(Suppl 1):P48.

\footnotetext{
Publish with ChemistryCentral and every scientist can read your work free of charge

"Open access provides opportunities to our colleagues in other parts of the globe, by allowing anyone to view the content free of charge." W. Jeffery Hurst, The Hershey Company.

- available free of charge to the entire scientific community

- peer reviewed and published immediately upon acceptance

- cited in PubMed and archived on PubMed Central

- yours - you keep the copyright

Submit your manuscript here:

http://www.chemistrycentral.com/manuscript/

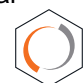
Chemistry Central
} 